\title{
A Daily Physical Activity and Diet Intervention for Individuals with Type 2 Diabetes Mellitus: A Randomized Controlled Trial
}

\begin{abstract}
Urbanisation, a sedentary lifestyle and increasing obesity due to westernization and changed eating habits have been identified as independent risk factors for diabetes in the South African population.

To establish the effectiveness of a daily walk and diet education intervention program.

A randomized controlled trial was performed. The study population consisted of men and women of all races, ages 40 to 65 with Type 2 Diabetes Mellitus

\begin{tabular}{|c|}
\hline $\begin{array}{l}\text { Van Rooijen Agatha J, PhD' } \\
\text { Viviers Christa M, MSc' } \\
\text { Becker Piet J, PhD' }\end{array}$ \\
\hline University of Pretoria \\
\hline
\end{tabular}
(DM) of duration at least one year attending the Steve Biko Diabetes Outpatient clinic. Patients of all weights were considered. Patients who had an $\mathrm{Hb} \mathrm{A}_{1 \mathrm{c}} \geq 8-9.5 \%$ were included in the sample group.

Four weekly group classes consisted of education considered essential for ongoing nutrition self-management and physical activity. Yamax pedometers and walk prescriptions based on the average number of steps walked in three days were used. The participants had a follow-up assessment at 16 weeks and one year.

The intervention and control groups were compared with respect to changes from baseline, using analysis of covariance (ANCOVA) with baseline values as covariates.

The difference between the intervention and control groups in the change in $H b A_{1 c}$ from the baseline was significant at the 16-week follow-up assessment $(p=0.041)$ and in the total cholesterol and LDL-cholesterol at the one-year follow-up assessment ( $p=0.047 ; p=0.014)$.

These results suggest that $\mathrm{Hb}_{1 c}$ can be improved over a period of four months. More frequent contact with the patients is necessary.
\end{abstract}

KEY WORDS: PHYSICAL ACTIVITY, DIETARY INTAKE, EDUCATION, TYPE 2 DIABETES MELLITUS.

\section{Introduction}

South Africa is one of the five countries in Sub-Saharan Africa with the highest number of people affected by diabetes (Mbanya 2009). Urbanisation, a sedentary lifestyle and increasing obesity due to westernization and changed eating habits have been identified as independent risk factors for diabetes in the South African population (Levitt et al 1999).

The South African Demographic and Health Survey (2003) established that $63 \%$ of women and $48 \%$ of men were inactive and that the prevalence of inactivity was higher in the urban than in the non-urban communities (Department of Health 2003). Physical activity, mainly consisting of walking, is significantly less in urban populations than in rural communities because walking in rural areas is used as a means of transport (Mbanya 2009).

Type 2 Diabetes Mellitus commonly occurs in persons who are obese and insulin-resistant in combination with impaired beta cell function (Haslett et al 2002).

Little time is spent on patient care and education because of inadequate staffing in South Africa (Whiting et al 2003). Clinical observations showed that the risk factors of the majority of patients attending Diabetes Outpatient Clinic at the Steve Biko Hospital were not well-controlled. The question asked was how to improve self-management and the clinical outcomes, taking into account the complexity of diabetes-related com- plications in patients in a tertiary hospital, the multicultural composition and the socio-economic circumstances of patients attending this clinic.

Intervention studies have consistently demonstrated that physical activity can improve glycaemic control in persons with Type 2 Diabetes Mellitus (T2DM).

In a Cochrane review by Norris et al (2005) on long-term non-pharmacological

\section{Correspondence to:}

Prof AJ van Rooijen

Department of Physiotherapy

P O Box 667 Pretoria, Gauteng

South Africa

0002

Email: Tania.VanRooijen@up.ac.za 
weight loss strategies interventions for adults with T2DM, the authors reported that among 53 persons receiving more intense physical activity interventions weight loss was $3.6 \%$ of baseline body weight.

Boule et al (2001) did a meta-analysis of controlled clinical trials on the effects of exercise on glycaemic control and weight in T2DM patients. A significant reduction of $0.66 \%$ in $\mathrm{HbA}_{1 \mathrm{c}}$ after aerobic exercise of 8 or more weeks was reported.

Sigal et al (2004) suggested that exercise should be performed at least 3 days per week and that there should not be more than 2 days between exercise bouts. This recommendation was included in the American Diabetes Association's recommendations for physical activity.

Di Loreto et al (2005) have shown that physical activity is an effective cost-saving tool in the care of T2DM in their study on the long-term impact of different amounts of physical activity. Brisk walking was the most common form of leisure time physical activity performed by their participants. The use of pedometers is a relative inexpensive and user-friendly way to provide goals for patients in steps per day. Pedometers have been shown to be valid for assessing physical activity in obese individuals by Swartz et al (2003). They have shown that pedometers correlate $(r=0.80-0.93)$ with more expensive accelerometers in controlled and field conditions.

More recently Yates et al (2009) did a review on the role of physical activity in the management of T2DM. They concluded that cost effective ways of increasing physical activity in persons with T2DM are investigated such as structured education to improve self management by these individuals.

Taylor JD et al (2009) investigated the impact of physiotherapy-directed exercise counseling in persons with T2DM. They reported that improvement in exercise outcomes comparable to those of supervised exercise could be obtained.

The aim of our study was to establish the effectiveness of a cost-effective daily walk and diet education intervention program in T2DM patients, attending the Steve Biko Diabetes Outpatient clinic.

\section{Methods}

\section{The setting and participants}

The study was conducted at the Diabetes Outpatient Clinic of the Steve Biko Academic Hospital in Gauteng Province, South Africa. This clinic is managed at a tertiary level and most patients have diabetes-related complications and are from low-income communities.

The study population consisted of men and women of all races, ages 40 to 65 years with T2DM for at least one year. Patients of all weights and who had an $\mathrm{HbA}_{1 \mathrm{c}}{ }^{1} \geq 8-9.5 \%$ were included in the sample group. Patients on diet therapy only, on glucose-lowering agents and/or insulin, were included.

Participants were screened for chest pain on effort, previous myocardial infarction, intermittent claudication, cerebro-vascular incidents, severe arthritis, retinopathy and general health by means of the London School of Hygiene Cardiovascular Questionnaire (Rose et al 1982). Cases where there were uncertainties regarding the aforementioned conditions, were referred to the attending specialist physician for clinical evaluation and advice about inclusion in the sample group. Participants, who were illiterate, were excluded, because completion of the Diabetes Knowledge questionnaire was required at all assessment points in the study.

\section{Ethics}

The protocol was approved by the Ethics Committee of the Faculty of Health Sciences of the University of Pretoria (Number 17/2005), as well as the Chief Executive Officer of the Steve Biko Hospital and was registered as a clinical trial with the National Department of Health (Number DOH-27-0107-1390). Informed consent was obtained.

\section{Baseline evaluation}

Baseline evaluation consisted of: fasting Glycated Haemoglobin $\left(\mathrm{HbA}_{1 \mathrm{c}}\right)$ and lipid blood samples (SYNCHRON LX

\footnotetext{
1 Glycated haemoglobin provides an accurate and objective measure of glycaemic control over a period of weeks to months (Haslett et al 2002)
}

1998); measurement of the blood pressure (Bailey et al 1993), body mass index (Lee and Nieman 2003) and capturing of biographic data, medication use and the Diabetes Knowledge Questionnaire Form B (Beeney et al 1994).

\section{Sample Size}

A sample of 22 patients per group was needed to demonstrate a difference in $\mathrm{HbA}_{1 \mathrm{c}}$ of $0.5 \%$ (from an average of 8.7 ) SD of 0.4 with $80 \%$ power. In anticipation of a dropout rate of $10 \%$, the recruitment goal was determined to be 25 patients per group. The sample size calculation was based on the average $\mathrm{HbA}{ }_{1 \mathrm{c}}$ and $\mathrm{SD}$ of the total database of patients attending the Steve Biko Hospital's Diabetes Outpatient Clinic. Patients were recruited from August 2006 to March 2008.

\section{Randomization}

Participants were randomized by means of block randomization (http:www. randomisation.com) Allocation concealment was ensured by means of sequentially numbered, sealed, opaque envelopes. The principal researcher assigned the participants to their groups. The research assistants and laboratory personnel measuring the primary and secondary outcomes were blinded to group assignment. The flow of the participants is illustrated in Figure 1.

\section{Intervention group}

The participants in the intervention group received usual care plus the study intervention. Participants attended four weekly group sessions. Astaged approach to education based on the Skilled-Helper Model was used to empower the par ticipants with knowledge and skills necessary for medical nutrition therapy with the ultimate goal to help participants to become better at helping themselves in their everyday lives (Frost 2003). A diagram of the model is demonstrated in Figure 2.

Topics included: planning, purchasing and preparing food and meals; sources of carbohydrate, protein and fat; reading of food nutrition labels; grocery shopping guidelines; modifying fat intake; use of sugar-containing foods; diabetic foods and sweeteners, as well as the Glycaemic 


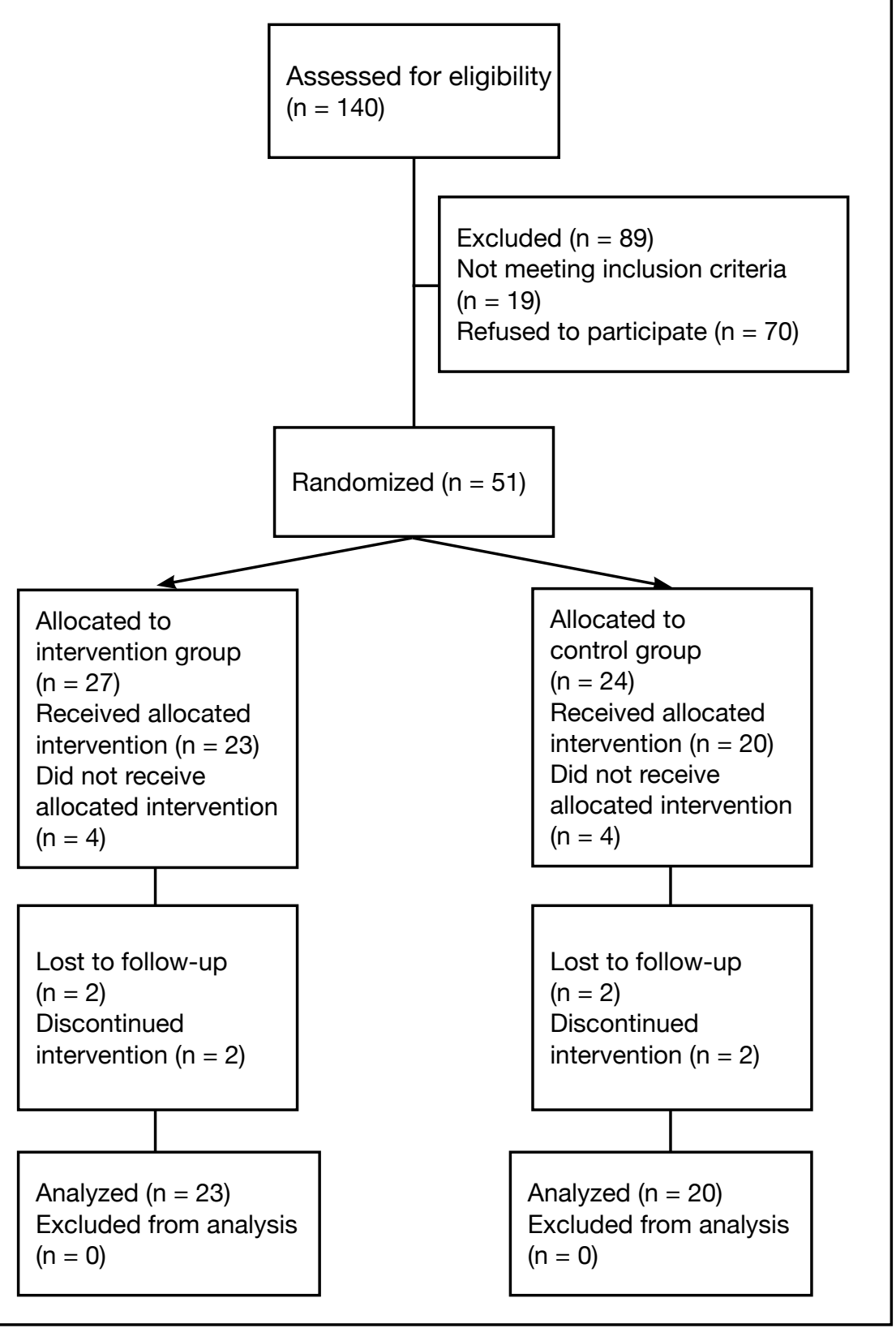

index and glycaemic load. No individualized dietary programs were given.

Each subject in this group received a Yamax SW-200pedometerC. Participants had to wear the sealed pedometers from the time they woke up until they went to bed at night for two week days and one weekend day to establish the baseline average number of steps for each patient. Personal goal setting was calculated on the average of the three-day step record (Tudor-Locke et al 2005). The aim was to motivate participants to walk at least 10000 steps per day five days per week. Participants received a logbook to document daily steps.

Our study was unique in the sense that all participants were examined by a podiatrist. The examination included vascular, neurological, dermatological and orthopedic assessments. Therapeutic insoles based on the shape and plantar pressure management and the type of shoe the subject wore were supplied to the participants if necessary (Owings et al 2008). It was hoped that this intervention would contribute to improved compliance to the walk program and comfort of the participants.

After the four group sessions, participants continued at home from week five of the program. They received motivating

Figure 1: Participant flow

STAGE 1

Current Scenario

1a - The story

(What's going on?)

$\checkmark$

$1 \mathrm{~b}$ - Blind spots

(What's really going on?)

1c - Leverage

(Focussing/prioritising)
STAGE 2

\section{STAGE 3}

Preferred Scenario

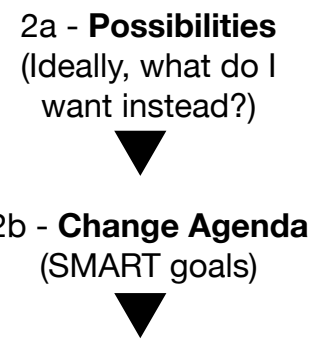

2c - Commitment

(Check goals are right)
Action Strategies

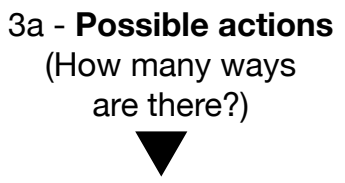

$3 b$ - Best fit strategies (What will work for me?)

3c - Plan

(What next and when?) 
text messages fortnightly. Participants were also encouraged to phone or to visit the researchers at the clinic whenever they had problems or questions.

The participants had a follow-up assessment at 16 weeks, during which time they had to return the pedometers, but continued with their respective walking and eating programs (Wolf et al 2004). Final assessment was conducted at one year.

\section{Control group}

The control group received the usual care and was waitlisted for an intervention similar to the intervention group after the study was completed. Participants in the control group were also followed up at 16 weeks and one year.

\section{Outcomes}

The primary outcome of this study was to establish the effectiveness of a daily walk and diet intervention program to decrease $\mathrm{HbA}_{1 \mathrm{c}}$ over a period of one year in T2DM individuals aged 40 to 65 years with an $\mathrm{HbA}_{1 \mathrm{c}} \geq 8-9.5 \%$.

Secondary outcomes were to establish the effect of the intervention on the blood lipid values, body mass index, and the diabetes knowledge of the participants.

\section{Statistical methods}

The intervention and control groups were compared with respect to changes from baseline, using analysis of covariance (ANCOVA) with baseline values as covariates using Stat Release 10 statistical software. Testing was done at 0.05 level of significance. Summary statistics were reported for the observed data, while confidence intervals were based on adjusted means following the ANCOVA. The $95 \%(C I)$ was based on adjusted analysis. No other analysis was performed. Parameters were analyzed individually, with the 12-month analysis being of primary importance.

Each item of the Diabetes Knowledge scale was assigned a score of one for a correct response and zero for an incorrect response. The total score for the scale was calculated by summing the scores of each of the 15 items to give a potential score range of 0 to 15 , with higher scores indicating better diabetes knowledge (Beeney et al 1994).

\section{Results}

Baseline data and numbers analyzed The baseline and final analysis biographic characteristics of the two groups were comparable. Two participants moved to other cities in South Africa and two participants who were previously unemployed for extended periods of time started new full-time jobs. In the control group one subject passed away. Two other participants dropped out because of socio-economic circumstances. The baseline biographic characteristics of all participants in the trial, those lost to follow-up, and those remaining in the trial to the end are demonstrated in Table1.

The difference in means between the groups was significant for $\mathrm{HbA}_{1 \mathrm{c}}$ at 16 weeks but not after one year. The decrease in the means of Total cholesterol and LDL-cholesterol was significantly lower between the groups after one year. The intervention group's scores on diabetes knowledge improved significantly at 16-weeks and 1-year.

The change in the means from baseline in the primary and secondary outcomes is demonstrated in Table 2.

\section{Adverse events}

No adverse events or side-effects were reported.

\section{Discussion}

The aim of this study was to establish the effectiveness of a cost-effective daily walk and diet education intervention program on $\mathrm{HbA}_{1 \mathrm{c}}$ in $\mathrm{T} 2 \mathrm{DM}$ patients.

The difference in means between the intervention and control groups in the change in $\mathrm{HbA}_{1 \mathrm{c}}$ from the baseline was significant at the 16-week followup assessment $(p=0.041)$. The difference between the groups could not be maintained at the one year follow-up assessment.

The decrease in the $\mathrm{HbA}_{1 \mathrm{c}}$ during the first four months could firstly be contributed to the group visits during this period. The interaction between participants contributed to shared-problem solving and encouraged the exchange of advice. Furthermore, participants could report problems with the walk program or feet, which were then addressed by the researchers and the podiatrist. Davis et al (2008) reported: "patients felt well cared for, better supported and more successful and confident" when participating in group classes.

The participants in our study did not reach a stage of self-efficacy in the selfmanagement phase of the study (Bandura 1997). Within the framework of the Skilled-Helper Model self-determination and self-control are essential for action. Participants who were unable to exert decisional self-control complemented by protracted self-control might have had an inability of manage their lives better (Frost 2003). Our sample may have been in the action stage of change but were not able to maintain the behavior after four months. This finding supports that of a study by Davis et al. (2009), who compared a one-year dietary intervention of a low carbohydrate to a low-fat diet on weight and glycaemic control and reported the greatest reduction in $\mathrm{HbA}_{1 \mathrm{c}}$ within the first three months of their study.

The two-weekly text messages were not intensive enough for the intervention group to sustain their motivation to maintain the change in physical activity and diet. Schillinger et al. (2009) conducted a one-year study on selfmanagement and reported that although glycaemic control improved and BMI changed, these changes were not significant enough in comparison with the changes seen in usual-care patients.

The difference from baseline in the total cholesterol and LDL-cholesterol was significant at the one year follow-up assessment ( $p=0.047 ; p=0.014$ ). This is in agreement with Miller et al (2002) who reported that patients who followed an intensive diabetes education program had optimal total cholesterol values at post test. Small weight losses result in improved LDL- and HDL-cholesterol levels even when the ideal BMI is not achieved (Krummel 2008). Moderateintensity physical activity of 60-90 minutes per day plays a major role in the maintenance of weight loss (Sigal et al 2004).

The difference between the baseline and both the 16-week and one year follow-up assessments in terms of the diabetes knowledge of the two groups were significant $(p<0.001 ; \mathrm{p}<0.002)$. 
Table 1: The baseline biographic characteristics of all participants in the trial, those lost to follow-up, and those remaining in the trial to the end. Values are percentages (numbers) unless stated otherwise.

\begin{tabular}{|c|c|c|c|c|c|}
\hline \multirow{2}{*}{\multicolumn{2}{|c|}{ Variables Means(SD) }} & \multicolumn{2}{|c|}{ Intervention Group } & \multicolumn{2}{|c|}{ Control Group } \\
\hline & & $\begin{array}{l}\text { Baseline } \\
(n=27)\end{array}$ & $\begin{array}{l}\text { Final anal } \\
(n=23)\end{array}$ & $\begin{array}{l}\text { Baseline } \\
(n=24)\end{array}$ & $\begin{array}{l}\text { Final anal } \\
(\mathrm{n}=20)\end{array}$ \\
\hline & ears [means(SD)] & $53.15(6.47)$ & 53.74 & $54.08(6.28)$ & 54 \\
\hline Gender & $\begin{array}{l}\text { Male } \\
\text { Female }\end{array}$ & $\begin{array}{l}14 \\
13\end{array}$ & $\begin{array}{l}11 \\
12 \\
\end{array}$ & $\begin{array}{c}7 \\
17 \\
\end{array}$ & $\begin{array}{r}5 \\
15 \\
\end{array}$ \\
\hline Race & $\begin{array}{l}\text { Black } \\
\text { Colored } \\
\text { White } \\
\text { Indian }\end{array}$ & $\begin{array}{c}33(9) \\
11(3) \\
56(15) \\
0\end{array}$ & $\begin{array}{c}39(9) \\
13(3) \\
48(11) \\
0\end{array}$ & $\begin{array}{c}58(14) \\
17(4) \\
21(5) \\
4(1)\end{array}$ & $\begin{array}{c}65(13) \\
20(4) \\
15(3) \\
0(0)\end{array}$ \\
\hline $\begin{array}{l}\text { Duration of } \\
\text { Diabetes }\end{array}$ & $\begin{array}{l}1-4 \text { years } \\
5-9 \text { years } \\
>10 \text { years }\end{array}$ & $\begin{array}{c}18.5(5) \\
37(10) \\
44.4(12)\end{array}$ & $\begin{array}{c}17.39(4) \\
39(9) \\
43(10)\end{array}$ & $\begin{array}{c}8.3(2) \\
12.5(3) \\
79.2(19)\end{array}$ & $\begin{array}{l}8.3(2) \\
15(3) \\
75(15)\end{array}$ \\
\hline Medication & $\begin{array}{l}\text { Insulin } \\
\text { Oral Hypoglycemic }\end{array}$ & $\begin{array}{l}77.8(21) \\
81.5(22)\end{array}$ & $\begin{array}{l}74(17) \\
78(18)\end{array}$ & $\begin{array}{l}91.7(22) \\
70.2(19)\end{array}$ & $\begin{array}{l}90(18) \\
80(16)\end{array}$ \\
\hline
\end{tabular}

Table 2: Comparison between groups with respect to the change in the means from baseline in primary and secondary outcomes.

\begin{tabular}{|c|c|c|c|c|c|c|}
\hline \multirow{2}{*}{$\begin{array}{c}\text { Outcomes } \\
\text { Observed } \\
\text { (adjusted) } \\
\text { means(SD) }\end{array}$} & \multicolumn{3}{|c|}{ 16-week } & \multicolumn{3}{|c|}{ 1-year } \\
\hline & $\operatorname{lntv}^{1}(n=25)$ & $\begin{array}{l}\text { Contr }{ }^{2} \\
(n=22)\end{array}$ & $\mathbf{P}(95 \% \mathrm{Cl})$ & Intv $(n=23)$ & $\begin{array}{l}\text { Contr } \\
(n=20)\end{array}$ & $\mathrm{P}(95 \% \mathrm{Cl})$ \\
\hline $\mathrm{HbA}_{1 \mathrm{c}}(\%)$ & $0.82(1.05)$ & $-0.04(-0.17)$ & $0.041^{\star}(0.66 ; 1.78)$ & $1.95(0.28)$ & $-0.01(-0.21)$ & $0.523(-0.25 ; 1.23)$ \\
\hline Total chol (mmol/l) & $0.04(0.04)$ & $0.04(0.04)$ & $0.983(-0.17 ; 0.17)$ & $0.16(0.16)$ & $-0.39(-0.32)$ & $0.047^{\star}(0.25 ; 0.71)$ \\
\hline Triglyc $(\mathrm{mmol} / \mathrm{l})$ & $0.02(0.01)$ & $-0.17(-0.16)$ & $0.588(-0.14 ; 0.49)$ & $-0.21(-0.25)$ & $-0.03(0.06)$ & $0.394(-0.79 ;-0.91)$ \\
\hline HDL-chol (mmol/l) & $-0.1(0.02)$ & $0.11(0.09)$ & $0.208(0.08 ; 0.17)$ & $0.03(0.05)$ & $0.08(0.06)$ & $0.875(-0.18 ; 0.17)$ \\
\hline LDL-chol (mmol/l & $-0.01(-0.05)$ & $-0.02(0.03)$ & $0.699(-0.29 ; 0.13)$ & $0.27(0.18)$ & $-0.52(-0.47)$ & $0.014^{\star}(0.41 ; 0.91)$ \\
\hline $\mathrm{BMI}\left(\mathrm{kg} / \mathrm{m}^{2}\right)$ & $0.79(0.81)$ & $0.39(0.39)$ & $0.243(0.35 ; 0.47)$ & $0.61(0.59)$ & $0.38(0.41)$ & $0.741(-0.35 ; 0.71)$ \\
\hline $\begin{array}{l}\text { Diabetes } \\
\text { Knowledge }\end{array}$ & $-2.96(-3.13)$ & $-0.95(-0.63)$ & $<0.001^{*}(-1.83 ;-3.17)$ & $-4.27(-4.48)$ & $-2.00(-1.82)$ & $<0.002^{*}(-1.9 ;-3.42)$ \\
\hline
\end{tabular}

* The difference between the groups was significant for $\mathrm{HbA}_{1 \mathrm{c}}$ at 16 weeks but not after one year. The decrease in Total cholesterol and LDL-cholesterol was significantly lower between the groups after one year. The intervention group's diabetes knowledge improved significantly at 16 -weeks and 1-year.

** $95 \% \mathrm{Cl}$ based on adjusted analysis. Parameters were analyzed individually with the 12 month analysis being of primary importance

1 Intv = Intervention group

2 Contr $=$ Control group 
This increase in knowledge in the intervention group could however not be translated to successful sustainable weight loss and physical activity. 'This finding concurs with Raynor et al (2008) who reported that a diet with an increased consumption of fruit and vegetables without a prescription to decrease energy intake resulted in a small weight loss that could not be maintained. People with Type 2 T2DM might have more difficulty in losing weight due to different genetic susceptibilities (Kaput et al 2007; Harris et al 2003)]. A genetic $\beta$-cell defect together with a reduction in insulin release could lead potentially to an increase in body weight (Ioannides 2008). The obesity phenotype of participants might furthermore have played a role in their response to regular exercise (Sasai et al 2009). Several meta-analyses have shown that physical activity interventions improve glycaemic control independently of weight loss. (Boule et al 2001; Thomas et al 2006). This finding once again emphasizes the role of the physiotherapist in the management of T2DM patients.

South Africa has few dedicated walking paths that may encourage people to walk more. The safety and security situation in the various neighborhoods where our sample resides may have contributed to limit walking from the intervention group (Department of Health 2007). Cost-effective ways of physical activity in this patient population is needed. One such possibility is resistance training in combination with aerobic exercise. A recent meta-analysis showed significant improvements in $\mathrm{HbAlc}$ and blood pressure with the aforementioned exercise (Snowling et al 2006).

\section{Limitations}

The attrition rate was high due to circumstances that we could not control. The results should be viewed as a pilot study, because it cannot be generalized to populations other than the Steve Biko patients.

\section{Recommendations for clinical practice}

The relapse of patients in the selfmanagement phase suggests the need for more frequent face-to-face contact with the participants when prescribing physical activity. Furthermore 60-90 minutes of moderate-intensity physical activity should be prescribed to maintain a steady weight loss in combination with a diet intervention. Consultation by a podiatrist when prescribing exercise programs may contribute to better compliance by participants. This emphasizes the need for team work between the physiotherapist, podiatrist and dietician to comprehensive management of the individual with T2DM. The use of the pedometers during the first four months of study motivated patients to walk and should be continued up to the one-year assessment. The use of motivational interviews for T2DM individuals struggling with self-management should be investigated to improve efficacy in management of the disease. It is suggested that the effect of a pharmacology intervention for weight loss, physical activity and individualised nutrition prescriptions be investigated in a population similar to our sample. The readiness to change of participants should be assessed before starting a self-management program. The use of food coupons as incentive for T2DM individuals who are successful in glycaemic control and maintaining their optimum weight should be investigated in a resource-poor community such as ours.

\section{Conclusions}

The effectiveness of a daily walk and diet education on $\mathrm{HbA}_{1 \mathrm{c}}$ blood lipid levels, BMI and diabetes knowledge in Type 2 T2DM patients was investigated in this study. The intervention consisted of four weeks of weekly contact with the research team and a self-management phase with text-message contact fortnightly up to one year. The results suggests that $\mathrm{HbA}_{1 \mathrm{c}}$ can be improved over a period of four months in a sample of patients with diabetes-related complications and who are from a poor socioeconomic background. More frequent contact with the patients and individualized nutrition prescriptions during the self-management phase may be more effective.

\section{Sources of support}

This study was supported by the Medical Research Council of South Africa and in part by the South African Sugar Association. No conflict ofinterest exists.

\section{Acknowledgements}

We acknowledge Prof Paul Rheeder (Specialist Physician), the assistance of the nursing staff at the Diabetes Clinic of the Steve Biko Academic Hospital, Kate Nkau (aT2DMinistrative support) and Helen Strydom (podiatrist).

\section{References}

Bailey GJ, Weiner DA, McCabe CH, Ryan TJ 1993 A review of common errors in the indirect measurement of blood pressure. Archives of Internal Medicine 153:2741-2748

Bandura A 1997 Self-efficacy: the exercise of control. pp198-421. W.H Freeman and Company, New York

Beeney LJ, Dunn SM, Welch G 1994 Handbook of Psychology and Diabetes. pp 159-89. Harwood Academic Publishers, Australia

Boule NG, Haddad E, Kenny GP, Wells GA, Sigal RJ 2003 Meta-analysis of the effect of structured exercise training on cardiorespiratory fitness in T2DM. Diabetologia 46:1071-1081

Type 2 Diabetes 2002 In: Haslett C, Chilvers ER, Boon NA, Colledge NR (eds) Davidson's Principles and Practice of Medicine, pp 654. Churchill Livingstone, London

Davis AM, Sawyer DR, Vinci LM 2008 The potential of group visits in diabetes care. Clinical Diabetes 26:58-63

Davis NJ, Tomuta N, Schechter C, Isasi CR, Segal-Isaacson CJ, Stein D, Zonszein J, WylieRosett JW 2009 Comparative study of a 1-year dietary intervention of a low-carbohydrate with a low-fat diet on weight and glycemic control in type 2 diabetes. Diabetes Care 32:1147-52

Department of Health, Medical Research Council, OrcMacro.2007. South Africa Demographic and Health Survey 2003, Pretoria: Department of Health

Di Loreto C, Fanelli C, Lucidi P et al 2005 Make your diabetes patients walk. Long-term impact of different amounts of physical activity on Type 2 Diabetes. Diabetes Care:28:1295-1302 
Frost G 2003 An introduction into Type 2 diabetes. In: Frost G, Dornhorst A, Moses R (eds) Nutritional management of Diabetes Mellitus, pp85-9. John Wiley and Sons Ltd, London

Harris SB, Petrella RJ, Leadbetter W 2003 Lifestyle interventions for type 2 diabetes. Canadian Familly Physician 49:11618-25

Kaput J, Noble J, Hatipoglu B, Kohrs K, Dawson K, Bartholomew 2007 Application of nutrigenomic concepts to T2DM. Nutrition, Metabolism \& Cardiovascular Diseases 17:89-103

Krummel DA 2008 Medical nutrition therapy for cardiovascular disease. In: Mahan LK, EscottStump S Krause's food, nutrition and diet therapy, $12^{\text {th }}$ edn. Saunders, Philadelphia

Lee RD. Nieman DC 2003 Nutritional assessment. $3^{\text {rd }}$ edn. McGraw-Hill, New York

Levitt NS, Steyn K, Lambert EV, Reagan G, Lombard CJ, Fourie JM, Rossouw K, Hoffman M 1999 Modifiable Risk Factors for T2DM in a Peri-Urban Community in South Africa. Diabetic Medicine 16:946-50

Mbanya, J-C, Ramiaya 2009 Diabetes Mellitus. In:Jamison DT, Feachem RG, Makgoba MW, Bos ER, Baingana KJ, Hofman J, Rogo KO, eds. Disease and Mortality in Sub-Saharan Africa. World Bank July 31 http://www.ncbi.nlm.nih.gov/ bookshelf/br.fcgi?book=T2DMssa\&part=A1752

Miller CK, Edwards L, Kissling G, Sanville L 2002 Nutrition education improves metabolic outcomes among older adults with diabetes mellitus: Results from a randomized controlled trial. Preventive Medicine 34:252-9

Muyinda H, Seeley J. Pickering H, Barton T 1997 Social aspects of AIDS-related stigma in rural Uganda. Health and Place 3:143-7

Norris SL, Zhang X, Avenell A, Gregg E, Brown T Schmid CH, Lau J 2005 Long-term nonpharmacological weight loss interventions for adults with T2DM. Cochrane Database of Systematic Reviews 2005, Issue 2.Art.No.: CD004095. DOI:10.1002.14651858.CD004095.pub2

Owings JM, Cavanagh PR, Woerner JL, Botek G, Frampton 2008 Custom therapeutic insoles based on both foot shape and plantar pressure measurement provide enhanced pressure relief. Diabetes Care 31: 839-44
Rose GA, Blackburn H, Gillium RF, Prineas RJ 1982 Cardiovascular survey methods. World Health Organization Geneva 62-7

Sasai H, Katayama Y, Nakata Y, Ohkubo H, Tanaka K 2009 Obesity phenotype and intraabdominal fat responses to regular aerobic exercise. Diabetes Research and Clinival Practice $84: 230-8$

Schillinger D, Wang F, Handley M, Hammer H 2009 The effects of self-management support on structure, process and outcomes among vulnerable patients with diabetes. Diabetes Care 32:559-66

Sigal RJ, Kenny GP, Wasserman DH, CastanedaSceppa C 2004 Physical activity/exercise and type 2 diabetes. Diabetes Care 27:2518-2539

Snowling NJ, Hopkins WG 2006 Effects of modes of exercise training on glucose control and risk factors for complications in type 2 diabetes patients: a meta analysis. Diabetes Care 29:25182527

Swartz AM, Bassett Jr DR, Moore JB, Thompson DL, Strath SJ 2003 Accuracy of an electronic pedometer in adults with varying body mass index levels. Medicine and Science in Sports and Exercise 35: S283.

Taylor JD, Fletcher JP, Tiarks J 2009 Impact of physical therapist-directed exercise counseling combined with fitness center-based exercise training on muscular strength and exercise capacity in people with type 2 diabetes: a randomized clinical trial. Physical Therapy 89:884-92

Thomas DE, Elliot E, Naughton G 2006 Exercise type for type 2 diabetes mellitus. Cochrane Database Systematic Rev3:CD002968

Tudor_Locke C, Burkett L, reis JP, Ainsworth BE, Macera CA, Wilson DK 2005 How many days of pedometer monitoring predict weekly physical activity in adults? Preventive Medicine 40:293-8

Vijan S, Stuart NS, Fitzgerald JT, Ronis DL, Hayward RA, Slater S, Hofer TP 2004 Barriers to following dietary recommendations in Type 2 diabetes. Diabetic Medince 22:32-8

Whiting DR, Hayes L, Unwin NC 2003 Challenges to Health Care for Diabetes in Africa. Journal of Cardiovascular Risk 10:103-10
Wolf AM, Conaway MR, Crowther JQ, Hazen KY, Bovbjerg VE, Nadler JL, Oneida B 2004 Translating lifestyle intervention to practice in obese patients with Type 2 Diabetes. Diabetes Care 7:1570-76

Yates Y, Khunti K, Troughton J, Davies M 2009 The role of physical activity in the management of T2DM. Post Graduate Medical Journal 85:129-133 
APPENDIX

Table 2: The baseline biographic characteristics of all participants in the trial, those lost to follow-up, and those remaining in the trial to the end. Values are percentages (numbers) unless stated otherwise.

\begin{tabular}{|c|c|c|c|c|c|c|c|c|}
\hline \multirow[b]{2}{*}{ Variables } & \multicolumn{4}{|c|}{ Intervention group } & \multicolumn{4}{|c|}{ Control group } \\
\hline & Baseline & $\begin{array}{l}\text { Lost to } \\
\text { follow- } \\
\text { up at } \\
16- \\
\text { weeks }\end{array}$ & $\begin{array}{l}\text { Lost to } \\
\text { follow- } \\
\text { up at } \\
1 \text {-year }\end{array}$ & $\begin{array}{l}\text { Final } \\
\text { analysis }\end{array}$ & Baseline & $\begin{array}{l}\text { Lost to } \\
\text { follow- } \\
\text { up at } \\
16- \\
\text { weeks }\end{array}$ & $\begin{array}{l}\text { Lost to } \\
\text { follow- } \\
\text { up at } \\
1 \text {-year }\end{array}$ & $\begin{array}{l}\text { Final } \\
\text { analysis }\end{array}$ \\
\hline $\begin{array}{l}\text { Age (years) } \\
\text { Mean (sd) }\end{array}$ & $\begin{array}{l}\%(n)=27) \\
53.15(6.47)\end{array}$ & $\begin{array}{l}\%(n)=2 \\
46\end{array}$ & $\begin{array}{l}\%(n)=4 \\
47\end{array}$ & $\begin{array}{l}\%(n)=23 \\
53.74\end{array}$ & $\begin{array}{l}\%(n)=24 \\
54.08(6.28)\end{array}$ & $\begin{array}{l}\%(n)=2 \\
51.33\end{array}$ & $\begin{array}{l}\%(n)=4 \\
52\end{array}$ & $\begin{array}{l}\%(n)=20 \\
54\end{array}$ \\
\hline $\begin{array}{l}\text { Gender } \\
\%(n) \\
\text { Male } \\
\text { Female }\end{array}$ & $\begin{array}{l}14 \\
13\end{array}$ & $\begin{array}{l}2 \\
0\end{array}$ & $\begin{array}{l}1 \\
1\end{array}$ & $\begin{array}{l}11 \\
12\end{array}$ & $\begin{array}{l}7 \\
17\end{array}$ & $\begin{array}{l}0 \\
2\end{array}$ & $\begin{array}{l}2 \\
0\end{array}$ & $\begin{array}{l}5 \\
15\end{array}$ \\
\hline $\begin{array}{l}\text { Race } \\
\text { Black } \\
\text { Colored } \\
\text { White } \\
\text { Indian }\end{array}$ & $\begin{array}{l}33(9) \\
11(3) \\
56(15) \\
0\end{array}$ & $\begin{array}{l}36(9) \\
12(3) \\
52(13) \\
0\end{array}$ & $\begin{array}{l}39(9) \\
13(3) \\
48(11) \\
0\end{array}$ & $\begin{array}{l}39(9) \\
13(3) \\
48(11) \\
0\end{array}$ & $\begin{array}{l}58(14) \\
17(4) \\
21(5) \\
4(1)\end{array}$ & $\begin{array}{l}64(14) \\
18(4) \\
14(3) \\
5(1)\end{array}$ & $\begin{array}{l}65(13) \\
20(4) \\
15(3) \\
0(0)\end{array}$ & $\begin{array}{l}65(13) \\
20(4) \\
15(3) \\
0(0)\end{array}$ \\
\hline $\begin{array}{l}\text { Smoker } \\
\%(n)\end{array}$ & 22.2(6) & $n=2$ & $\mathrm{n}=2$ & $17.39(4)$ & $16.7(4)$ & 0 & 0 & $16.7(4)$ \\
\hline $\begin{array}{l}\text { Duration of } \\
\text { diabetes } \\
\%(n) \\
1-4 \text { years }\end{array}$ & $18.5(5)$ & $n=1$ & 0 & $17.39(4)$ & 8.3(2) & 0 & 0 & 8.3(2) \\
\hline $5-9$ years & $37(10)$ & $n=1$ & 0 & 39(9) & $12.5(3)$ & 0 & 0 & 15(3) \\
\hline$>10$ years & $44.4(12)$ & 0 & $n=2$ & $43(10)$ & $79.2(19)$ & $\mathrm{n}=2$ & $\mathrm{n}=2$ & $75(15)$ \\
\hline $\begin{array}{l}\text { Education } \\
\%(n) \\
\text { Completed } \\
\text { school }\end{array}$ & $37(10)$ & $n=2$ & $\mathrm{n}=2$ & $26(6)$ & $12.5(3)$ & 0 & $n=1$ & 10(2) \\
\hline $\begin{array}{l}\text { Employment } \\
\%(n) \\
\text { Unemployed }\end{array}$ & $56.52(13)$ & $n=1$ & $n=1$ & $48(11)$ & $70(14)$ & $\mathrm{n}=2$ & $n=2$ & $50(10)$ \\
\hline $\begin{array}{l}\text { Medication } \\
\%(n) \\
\text { Insulin }\end{array}$ & $77.8(21)$ & $n=2$ & $\mathrm{n}=2$ & $74(17)$ & $91.7(22)$ & $\mathrm{n}=2$ & $n=2$ & $90(18)$ \\
\hline $\begin{array}{l}\text { Oral } \\
\text { Hypoglymecic }\end{array}$ & $81.5(22)$ & $n=2$ & $n=2$ & $78(18)$ & $70.2(19)$ & $n=1$ & $=2$ & $80(16)$ \\
\hline
\end{tabular}

